\title{
Determining the site effects of 23 October 2011 earthquake (Van province, Turkey) on the rural areas using HVSR microtremor method
}

\author{
İsmail AkKaya ${ }^{1, *}$, Ali ÖZvan ${ }^{2}$, MÜCIP TAPAN ${ }^{3,4}$ and M Alper ŞengüL ${ }^{5}$ \\ ${ }^{1}$ Department of Geophysical Engineering, Yüzüncü Yıl University, Van, Turkey. \\ ${ }^{2}$ Department of Geological Engineering, Yüzüncü Yıl University, Van, Turkey. \\ ${ }^{3}$ Department of Civil Engineering, Yüzüncü Yıl University, Van, Turkey. \\ ${ }^{4}$ Disaster Management and Earthquake Research and Application Center, Yüzüncü Yıl University, Van, Turkey. \\ ${ }^{5}$ Department of Geological Engineering, Istanbul University, Istanbul, Turkey. \\ ${ }^{*}$ Corresponding author.e-mail: iakkaya79@gmail.com
}

A magnitude of $7.1 \mathrm{Mw}$ earthquake struck Van city on October 23, 2011. Although, construction practices of all rural housing units are similar in the region, the earthquake caused massive damage to villages located on soft soils in northern region of the city. In this study, the effects of soil conditions on damaged housing units were determined by conducting horizontal to vertical spectral ratios of microtremor (HVSR) measurements. The level of damage in the villages that are settled on lacustrine and stream sediments has verified that the damage correlates well with comparatively high HVSR peak period and HVSR peak amplitude values in the range of $0.2-1.6 \mathrm{~s}$ and $4-10$, respectively. The HVSR peak period and HVSR peak amplitude levels on rock units are in the range of $0.1-0.2 \mathrm{~s}$ and $1.5-2$, respectively. It is important to note that hillside effect is found to be another key factor that increased the level of damage to the housing units in some villages.

\section{Introduction}

A destructive earthquake with a moment magnitude $(\mathrm{Mw})$ of 7.1 occurred on October 23, 2011 at 13:41 local time, in the $20 \mathrm{~km}$ northern side of Van, Turkey (Kandilli Observatory and Earthquake Research Institute (KOERI), 2011). The earthquake primarily affected urban areas of Van and Erciş in Turkey, caused 644 casualties and also destroyed many buildings.

The structural damages caused by Van earthquake, have shown the importance of the quality of construction as well as the seismic wave phases, earthquake source properties and local geotechnical conditions. Seismic waves cause a variety of incidents such as liquefaction, seismic amplification, strength reduction, etc., while passing through the layers of soil. From this perspective, the effect of soil conditions on the structure under dynamic loads can be one of the key factors that will greatly affect the level of damage caused by earthquakes. Regional geology, tectonic and topographical conditions can cause varying degrees of damages in close proximity when exposed to the same seismic motions by changing the properties of the earthquake waves (Ansal 1999a, b).

HVSR microtremor technique, known as Nakamura's technique, has received great attention from all over the world with its simplicity together with quick information about dynamic characteristics

Keywords. Van-Turkey; rural areas; earthquake; ambient noise; HVSR; soil conditions. 
of ground and structures. HVSR technique has been used by many other researchers (Lermo and Chavez-Garcia 1993, 1994; Lachet and Bard 1994; Field and Jacob 1995; Gitterman et al. 1996; Theodulidis et al. 1996; Bard 1998; Konno and Ohmachi 1998; Mucciarelli 1998; Zaslavsky et al. 2000; Fah et al. 2001; Dikmen and Mirzaoglu 2005; Asten 2006; Bonnefoy-Claudet et al. 2006; Hasancebi and Ulusay 2006; Eskişar et al. 2013; Asten et al. 2014; Akkaya 2015). Although several researchers claimed that the theoretical background of this technique is not clear, there have been many successful experimental studies performed (Nakamura 2008). In the past decade, Nakamura method is widely used for estimation of site effect under seismic waves. Lermo and Chavez-Garcia (1993, 1994) applied the HVSR method to estimate the empirical transfer function in Mexico. Their results showed that the HVSR can estimate the dominant frequency at a site based on earthquake data. Field and Jacob (1995) applied the HVSR method in Flushing Meadows, New York. The results suggested that the HVSR is an effective and reliable tool to calculate the fundamental frequency of a layered sedimentary basin. The research done by Suzuki et al. (1995) in Hokkaido, Japan showed that the dominant frequency obtained from HVSR was in good agreement with the predominant frequency estimated from the thickness of an alluvial layer. Dikmen and Mirzaoğlu (2005) used this method to determine seismic microzonation of Yenisehir-Bursa which is located at the northwestern part of Turkey. Ozel et al. (2004) estimated Swave velocity structure in the district of AvcilarIstanbul using array microtremor measurements. Eskişar et al. (2013) utilized Nakamura's method in the northern coast of İmir Bay, Turkey. Fundamental period map obtained from $\mathrm{H} / \mathrm{V}$ spectral ratio method illustrated the characteristics of weak soil conditions and the presence of bedrock level under thick alluvial soils. Their results showed that the microtremor investigations have proved to be an effective tool for assessment of local soil conditions in case of thick soft sediments in the northern coast of Izmir Bay.

The HVSR has been studied to explain its strengths and limitations by many researchers (BonnefoyClaudet et al. 2006; Bard 2008; Pilz et al. 2009; Lunedei and Albarello 2010). Usually, the HVSR reveals the site dominant frequency, but the amplitude of the HVSR is not well understood (Pilz et al. 2009). In order to overcome the limitations of Nakamura's method, SESAME (2004) published HV User's Guidelines. Therefore, HVSR analysis in this study was performed following the rules outlined in SESAME (2004).

Within the scope of this study, the effect of soil conditions on damaged buildings was determined by conducting horizontal to vertical spectral ratio of microtremor (HVSR, ambient noise) measurements in the villages affected by the Van earthquake. For this purpose, HVSR measurements with a 10-30 min data record were conducted at 80 locations in the villages of Van during the period of June-July 2013. These villages are as follows: Bardakçı, Topaktaş, Arısu, Zeve, Çitören, Çakırbey, Ermişler, Gedikbulak, Şahgeldi, Tabanl,, Dağönü, Guveçli, Göllü, A ğartı, Gülsünler, Yumrutepe, Mollakasım, Alaköy, Tevekli, Özkaynak, Hıdır, Ocaklı, Yemlice, Akçaören, Koçköy, Yalnızağaç, Kasımoğlu, Adıgüzel (figure 1). After performing the proper data-processing steps based on HVSR microtremor records taken from the villages, peak frequencies/periods and peak amplitude values (amplification) of HVSR were calculated. The results were checked with the level of damage in the buildings considering regional tectonics, geological and geophysical conditions.

\section{Geology of the region}

Many different types of rocks, from Paleozoic period to the current period have been found around Lake Van basin (figure 2). The basin generally consists of Oligocene-Lower Miocene aged marine sediments called Van Formation (MTA 2007). Bitlis massive metamorphic rocks are mainly observed on the surface from southern to the eastern part of the basin (Ternek 1953; Ketin 1977; Yılmaz et al. 1981; Göncüoğlu and Turhan 1984). Volcanoclastic deposits are found around Nemrut and Süphan volcanoes located in the western side of the region. In addition, lavas extending from Etrüsk and Tendürek volcanoes are found in the northern and northeastern parts of the region (Güner 1984; Yılmaz et al. 1987). Clastic ophiolitic units are derived from Yüksekova Complex and settled on Upper Cretaceous-Paleocene, while sedimentary rocks are observed in the southern and southeastern parts of the basin (Acarlar et al. 1991). Lacustrine sediments and fluvial deposits from Pliocene period outcrop in the eastern and northeastern parts of the basin.

The villages included in this study are generally located on Quaternary-aged terrestrial sediments composed of Van Formation (composed of Oligocene-Lower Miocene aged sandstone, conglomerate, siltstone, claystone, calcarenite rock types), Adilcevaz limestone (composed of Lower Miocene reef limestone), Aktaş Formation (composed of Middle Miocene conglomerate), Kurtdeliği Formation (composed of Upper Miocene aged Yağlık basalt, Upper Miocene aged gypsum, sandstone, conglomerate, siltstone, claystone and Miocene-aged rock formations), respectively (MTA 


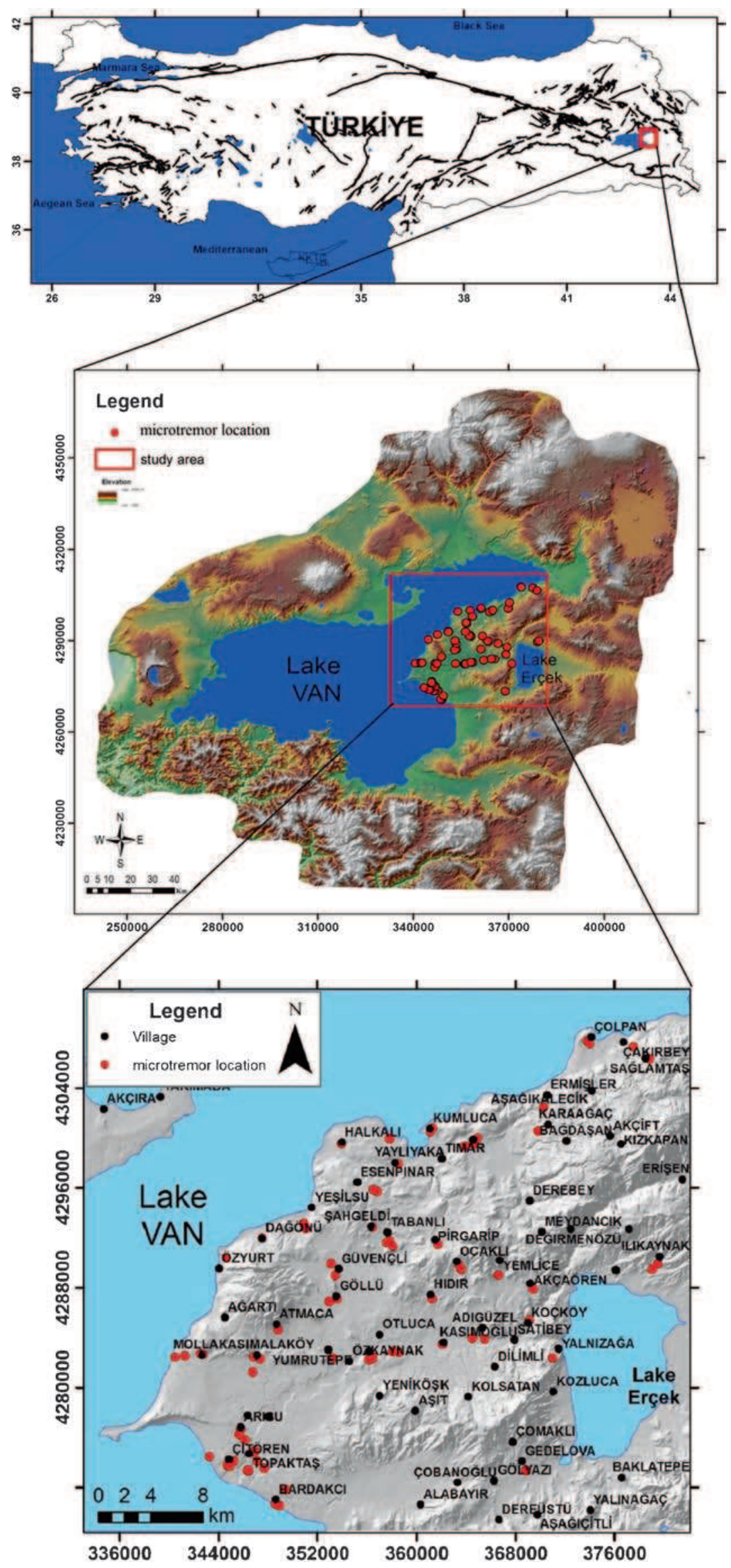

Figure 1. Location map of the study area. 

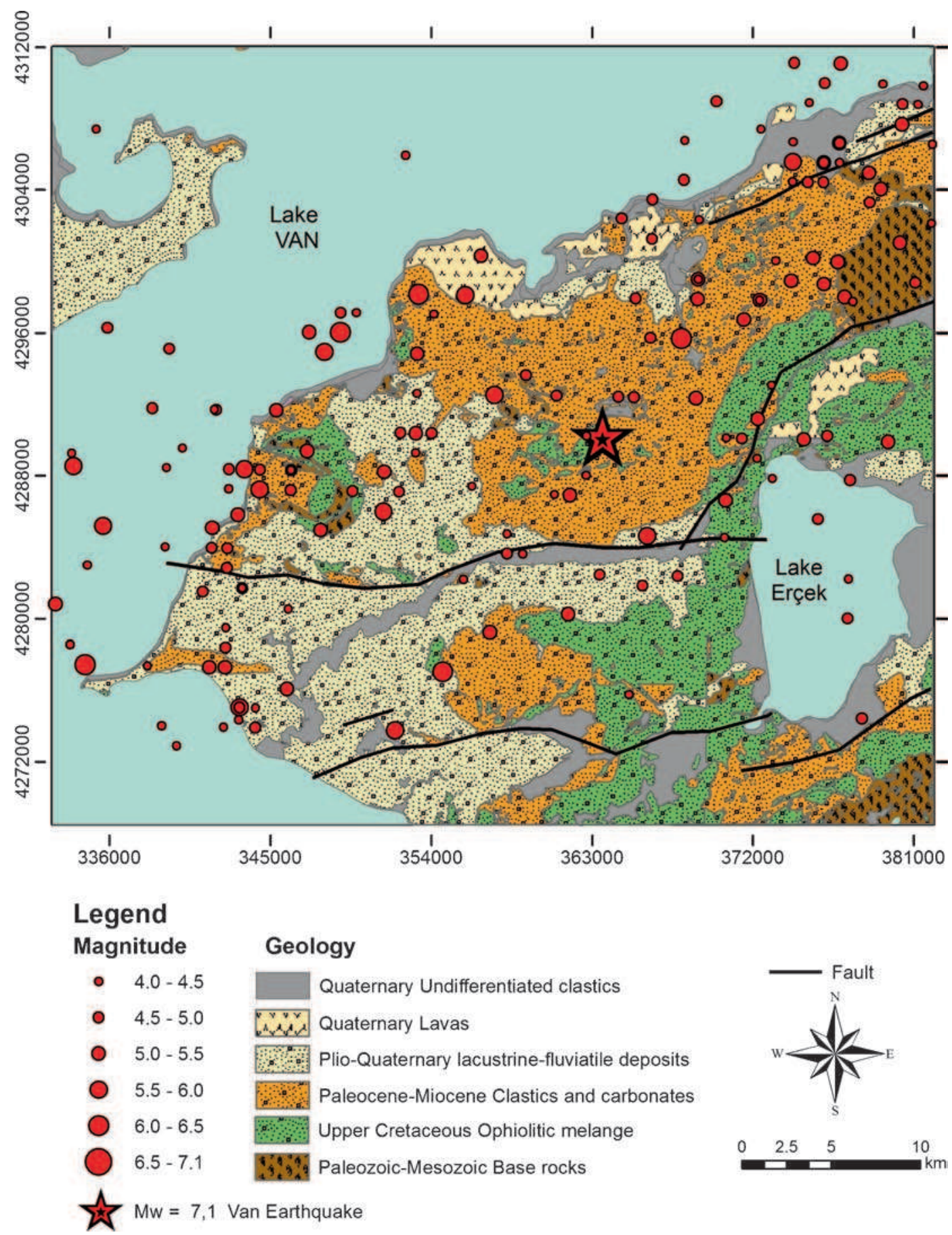

Figure 2. Geological map of the study area (modified from MTA 2008).

2007, 2008). Additionally, sedimentary and volcanic formations of Plio-Quaternary period dominated by fluvial and lacustrine environments outcrop along the villages investigated in the study. It is known that the water level of Lake Van was at its highest point 16,000 years ago; however, the water level dramatically dropped down to its current level over the last 10,000 years (Degens et al. 1978). As a result of this movement in the water level, alluvial fan deposits, lacustrine sediments and fluvial deposits, alluviums, current lacustrine and fluvial sediments, talus deposits have become the most common soil types in the geology of the region, which are commonly called Plio-Quaternary deposits (MTA 2007, 2008).

Some of the villages that were severely affected by the earthquake (Çitören, Arısu, Mollakasım, Alaköy, Yumrutepe, Atmaca, Göllü, Güveçli, Tabanll, Dağönü, Şahgeldi, Yeşilsu, Ocaklı, Pirgarip, Hıdır, Aşağıgölalan, Esenpınar, Sağlamtaş, Çakırbey) were located on Oligocene-Miocene clastic rocks composed of sandstone, siltstone and 
conglomerate, and marl sequences. In these villages, soil is composed of stiff-to-loose talus deposits. Other severely affected villages were located in the flood plain on Karasu River (Bardakçı, Topaktaş, Özkaynak, Gülsünler, Kasımoğlu, Satıbey and Koçköy) which overlies on Quaternary alluvial deposits and terraces. Volcanic deposits are situated on Halkalı, Timar (Gedikbulak), Çolpan, Karaağaç and Yaylıkaya regions. Kumluca village is situated on volcanic deposits and coastal sediments.

\section{Seismicity of the region}

The study area is located in the northern side of Bitlis-Zagros suture zone that caused the neotectonic period of eastern Anatolia region. Bitlis-Zagros suture zone was developed as a result of Arabian-Eurasian collision. Bitlis ocean's closure produced Çüngüş Basin by the Late Miocene Period (Sengör and Kidd 1979; Koçyiğit et al. 2001). Eastern Anatolia region had new

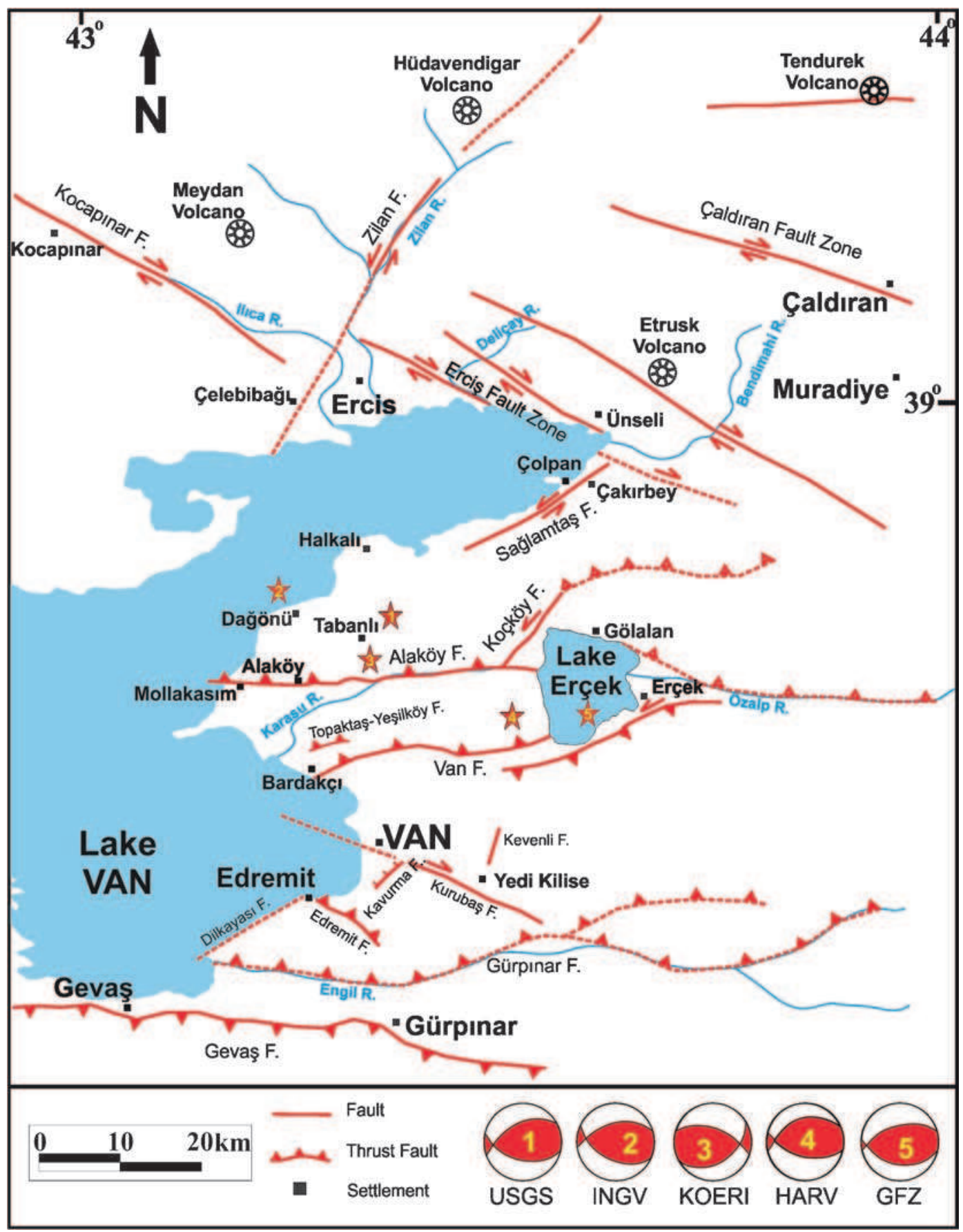

Figure 3. Major active faults in eastern part of Lake Van and epicenter of the main shock that occurred on October 23, 2011. Beachballs are showing focal mechanism solutions of different institutions. TF: thrust fault, RL: right-lateral strike slip fault, LL: left-lateral strike slip fault, NF: normal fault. Ruptured faults of 23 October 2011 are Van and Topaktaş faults (modified from Poyraz et al. 2011). 


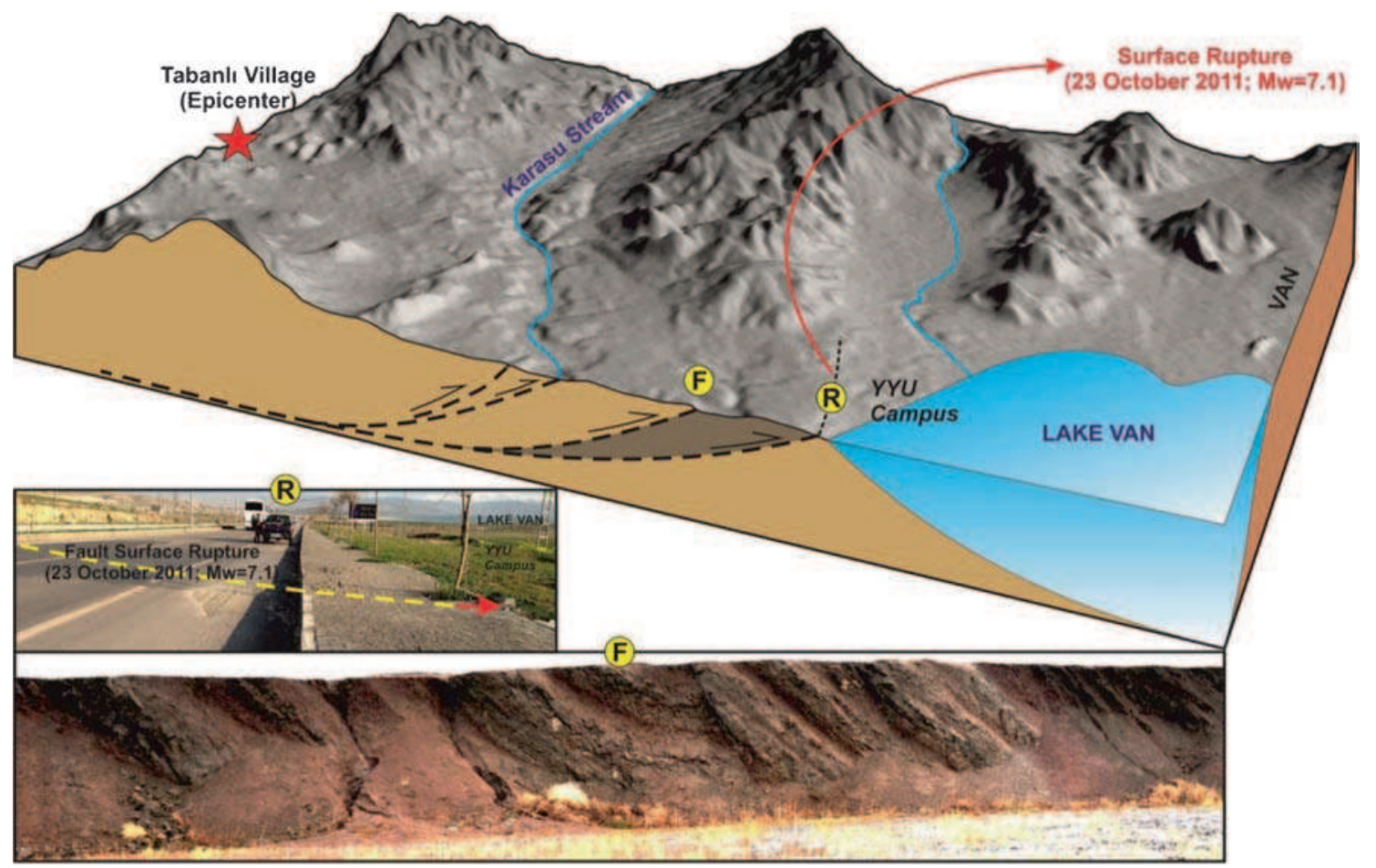

Figure 4. Block diagram showing main thrust zones in the region and ruptured faults after Van earthquake (R: surface rupture, F: Van Thrust Fault).

morphological characteristics followed by this collision (Şaroğlu and Güner 1981).

Fault plane solutions, which were obtained by various institutions, display that the earthquake is activated by thrust fault mechanism (figure 3). According to the Disaster and Emergency Management Presidency of Turkey (AFAD), approximately 12,000 aftershocks between the magnitude values of 2.0 and 5.0 were recorded in this region (AFAD 2011).

Lake Van and its surrounding area comprise seismically-active fault systems (strike-slip fault, normal fault and reverse fault) with diverse magnitudes and properties (Aksoy and Tatar 1990; Koçyiğit et al. 2001; Akkaya and Köse 2002; Çiftci et al. 2004; Özvan et al. 2005). These fault systems are as follows: Çaldıran fault zone, Erciş fault zone, Süphan fault zone, Muş fault zone, Güzelsu fault zone, Başkale fault zone, Van fault zone, Özalp fault zone, Gevaş fault zone and other individual faults (Bulanık fault, Malazgirt fault, Kuscu fault, Çakırbey fault, Alabayır fault, Erçek fault, etc.) (Koçyiğit et al. 2001). Özalp and Gevaş fault zones are in the form of $\mathrm{E}-\mathrm{W}$ trending reverse fault; whereas Çaldıran and Erciş faults are in the form of NW-SE trending right lateral strike-slip fault zones; whereas Süphan and Başkale fault zones are in the form of NE-trending left lateral strikeslip fault zones, respectively (Koçyiğit et al. 2001) (figure 3). Van earthquake that occurred on
October 23, 2011 was recorded to be the most destructive earthquake resulting from the movement of reverse faults in Turkey (Koçyiğit et al. 2011). Earthquake-induced surface fault rupture and block diagram can be seen in figure 4. Especially after 2000, the region had relatively higher seismic activities.

The earthquake happened in Van on October 23, 2011 which was recorded by 22 different accelerometer stations, were located on different types of soils, of the National Strong Ground Motion Observation Network of Prime Ministry Disaster and Emergency Management Presidency (AFAD) in Turkey. According to the nearest station (Muradiye) located $42 \mathrm{~km}$ away from the epicenter of this earthquake, the peak ground acceleration values are recorded as $178.5 \mathrm{~cm} / \mathrm{s}^{2}$ in the northsouth direction, $168.5 \mathrm{~cm} / \mathrm{s}^{2}$ in the east-west direction and $75.5 \mathrm{~cm} / \mathrm{s}^{2}$ in the vertical direction, respectively (AFAD 2011).

\section{Microtremor measurements and data analysis}

One of the most important problems in the studies aiming to identify earthquake-induced damages depending on soil condition is determining the dynamic properties of soil layers. The statistical studies related to earthquake damages in 
these regions, where equal seismic intensities were observed, show different levels of earthquake damages in almost identical structures. HVSR technique, known as Nakamura's technique, which was introduced by Nakamura (1989), is used for determining HVSR peak frequencies or periods and HVSR peak amplitude values (amplification) based on recording the ambient seismic noise (generally in the range $0.1-1$ micron) and microtremor (between 0.005 and $2 \mathrm{~s}$ ) (Kanai and Tanaka 1954, 1961). HVSR method is based on the spectral ratio of the horizontal vs. vertical components of microtremors observed at the same site. After Nakamura (1989), this technique was tested

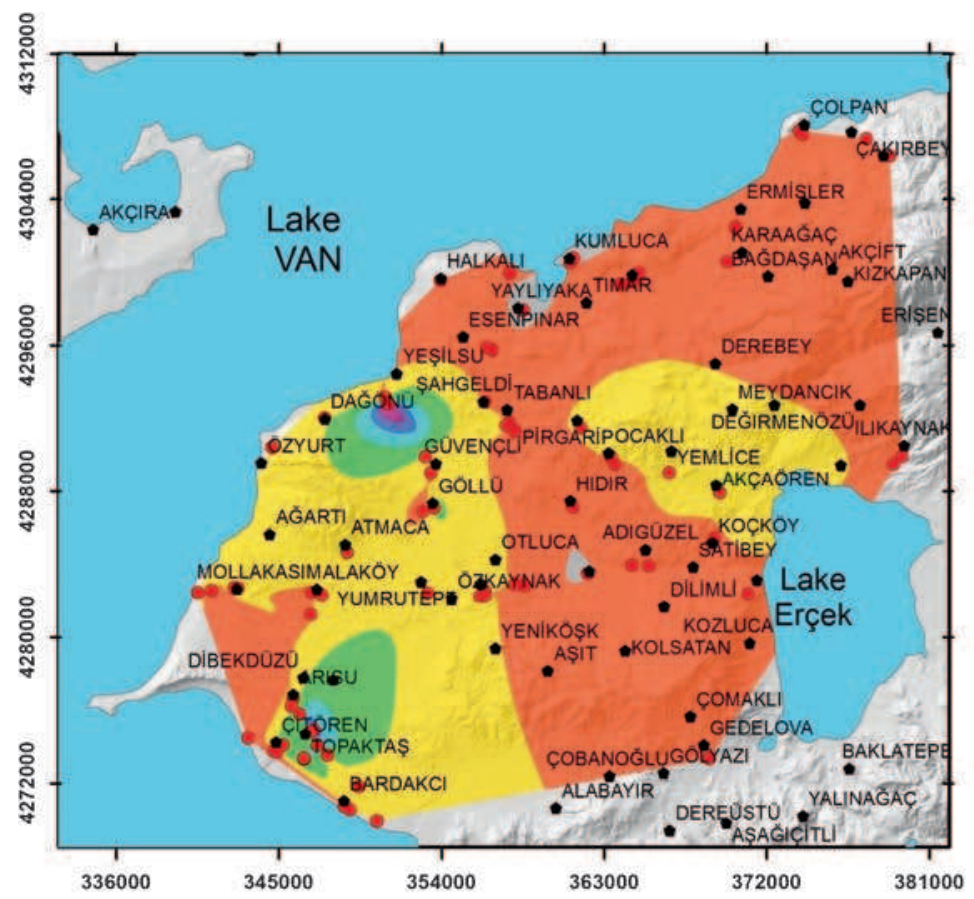

\section{Legend \\ - Village \\ - Microtremor Location}

\section{HVSR peak amplitude values}

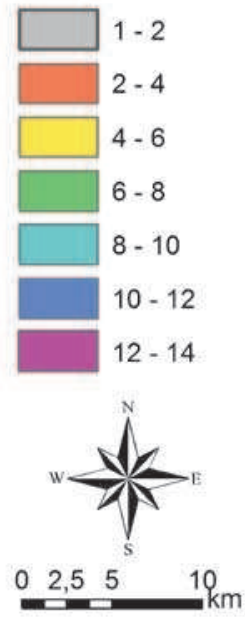

(a)

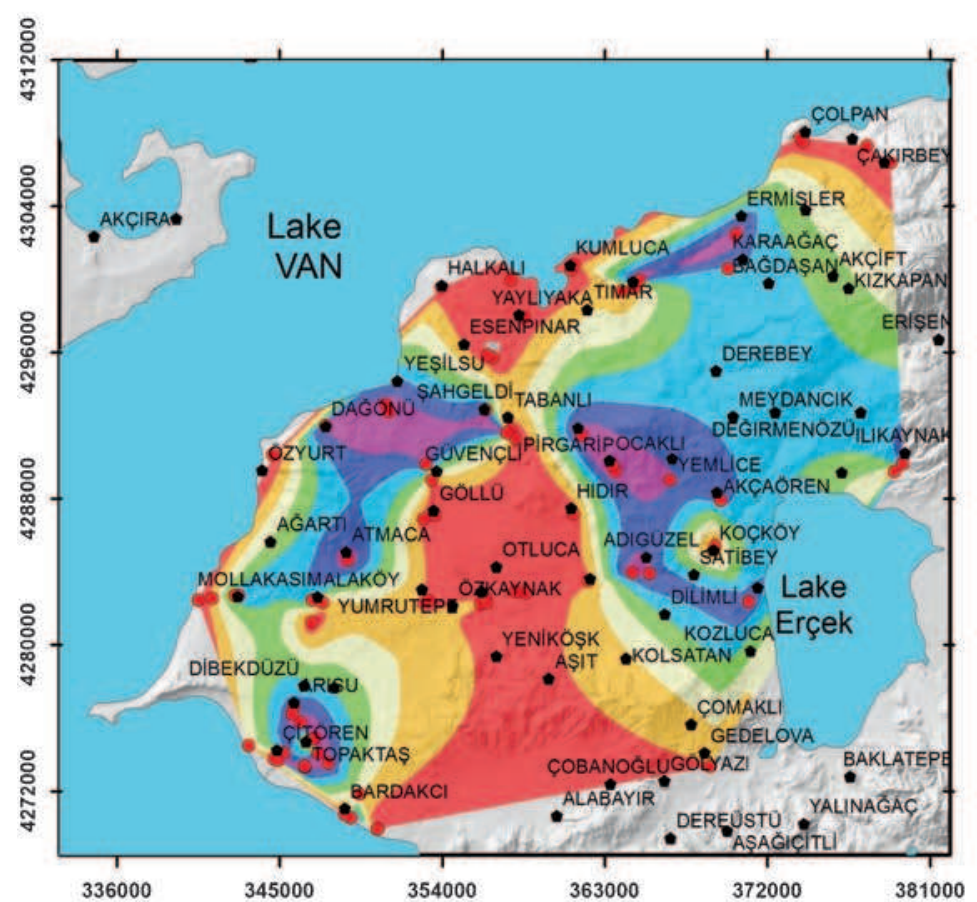

(b)

\section{Legend}

- Village

- Microtremor Location

HVSR peak period (s)

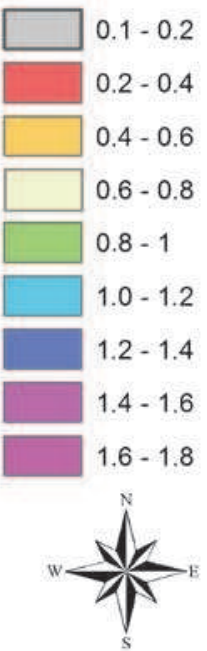

\begin{tabular}{lll}
0 & 2,5 & $5 \quad 10$ \\
\hline
\end{tabular}

Figure 5. HVSR measurements obtained from the records of HVSR peak amplitude values (a) and HVSR peak period values (b). 
Table 1. Comparison of HVSR peak values, local soil conditions and final damage assessment results of Governorship of Van.

\begin{tabular}{|c|c|c|c|c|c|c|c|c|c|c|}
\hline \multirow{2}{*}{$\begin{array}{l}\text { Village } \\
\text { name }\end{array}$} & \multirow{2}{*}{$\begin{array}{l}\text { HVSR peak } \\
\text { period }\end{array}$} & \multirow{2}{*}{$\begin{array}{l}\text { HVSR peak } \\
\text { frequencies }\end{array}$} & \multirow{2}{*}{$\begin{array}{c}\text { HVSR peak } \\
\text { amplitude }\end{array}$} & \multirow[b]{2}{*}{ Soil type } & \multirow[b]{2}{*}{ Damage type } & \multicolumn{5}{|c|}{ Damage $(\%)$} \\
\hline & & & & & & No damage & Minor & Moderate & Heavy & Collapse \\
\hline Adıgüzel & 1.40 & 0.71 & 3.94 & Plio-Quaternary sediments & Moderate & 4 & 17 & 79 & 0 & 0 \\
\hline Alaköy & 1.12 & 0.89 & 5.46 & Plio-Quaternary sediments & Heavy & 2 & 13 & 0 & 28 & 57 \\
\hline Akçaören & 1.28 & 0.78 & 4.13 & Ophiolitic melange & Minor & 8 & 38 & 28 & 23 & 3 \\
\hline Arisu & 1.33 & 0.75 & 5.28 & Alluvium & Heavy & 6 & 16 & 4 & 74 & 0 \\
\hline Atmaca & 1.56 & 0.64 & 4.30 & Plio-Quaternary sediments & Moderate & 7 & 40 & 1 & 52 & 0 \\
\hline Bardakçı & 0.54 & 1.84 & 4.60 & Plio-Quaternary sediments & Moderate & 8 & 38 & 0 & 46 & 8 \\
\hline Çakırbey & 0.20 & 4.91 & 2.84 & Alluvium-clastic rocks & Moderate & 7 & 19 & 0 & 74 & 0 \\
\hline Çitören & 1.58 & 0.63 & 4.87 & Plio-Quaternary sediments & Heavy & 2 & 2 & 1 & 80 & 15 \\
\hline Çolpan & 0.21 & 4.70 & 2.13 & Alluvium-volcanic unit & Minor & 23 & 37 & 30 & 10 & 0 \\
\hline Dağönü & 1.49 & 0.67 & 6.57 & Alluvium & Heavy & 0 & 0 & 0 & 100 & 0 \\
\hline Ermişler & 1.15 & 0.87 & 3.14 & Clastic rocks & Moderate & 2 & 28 & 18 & 37 & 15 \\
\hline Esenpinar & 0.17 & 5.87 & 2.22 & Alluvium-volcanic unit & Moderate & 9 & 24 & 55 & 12 & 0 \\
\hline Göllü & 0.32 & 3.09 & 6.85 & Plio-Quaternary sediments & Heavy & 0 & 11 & 0 & 69 & 20 \\
\hline Güveçli & 1.28 & 0.78 & 6.88 & Plio-Quaternary sediments & Heavy & 0 & 0 & 0 & 100 & 0 \\
\hline Halkalı & 0.29 & 3.34 & 2.95 & Alluvium-volcanic unit & Heavy & 0 & 10 & 1 & 37 & 52 \\
\hline Hidır & 1.51 & 0.66 & 2.73 & Clastic rocks & Moderate & 5 & 41 & 0 & 54 & 0 \\
\hline Ilıkaynak & 1.36 & 0.73 & 3.49 & Alluvium-ophiolitic melange & Moderate & 0 & 35 & 0 & 60 & 5 \\
\hline Kumluca & 0.19 & 5.11 & 2.04 & Alluvium-volcanic unit & Heavy & 0 & 1 & 4 & 95 & 0 \\
\hline Koçköy & 0.42 & 2.38 & 2.03 & Ophiolitic melange & Minor & 78 & 5 & 0 & 17 & 0 \\
\hline Mollakasım & 1.28 & 0.78 & 4.69 & Alluvium & Heavy & 8 & 7 & 0 & 85 & 0 \\
\hline Ocaklı & 1.75 & 0.57 & 4.20 & Clastic rocks & Moderate & 21 & 18 & 0 & 61 & 0 \\
\hline Özkaynak & 0.19 & 5.15 & 4.25 & Plio-Quaternary sediments & Heavy & 0 & 19 & 0 & 81 & 0 \\
\hline Özyurt & 0.17 & 5.85 & 5.66 & Alluvium & Heavy & 1 & 0 & 4 & 95 & 0 \\
\hline Tabanlı & 0.15 & 6.35 & 2.08 & Clastic rocks & Moderate & 0 & 9 & 77 & 14 & 0 \\
\hline Timar & 0.30 & 3.28 & 4.96 & Alluvium-volcanic unit & Heavy & 2 & 3 & 1 & 94 & 0 \\
\hline Topaktaş & 1.47 & 0.68 & 8.98 & Alluvium-clastic rocks & Heavy & 0 & 2 & 1 & 97 & 0 \\
\hline Yaylıyaka & 0.25 & 3.90 & 1.94 & Alluvium-volcanic unit & Moderate & 0 & 3 & 27 & 70 & 0 \\
\hline Yemlice & 1.42 & 0.70 & 4.69 & Clastic rocks & Heavy & 1 & 1 & 0 & 64 & 34 \\
\hline Yeşilsu & 1.16 & 0.86 & 4.79 & Alluvium-clastic rocks & Moderate & 0 & 23 & 10 & 48 & 19 \\
\hline Yumrutepe & 0.33 & 3.03 & 5.64 & Plio-Quaternary sediments & Heavy & 3 & 5 & 2 & 68 & 22 \\
\hline
\end{tabular}


experimentally and theoretically at many sites by different researchers (Lermo and Chavez-Garcia 1993, 1994; Lachet and Bard 1994; Field and Jacob 1995; Gitterman et al. 1996; Theodulidis et al. 1996; Mucciarelli 1998; Konno and Ohmachi

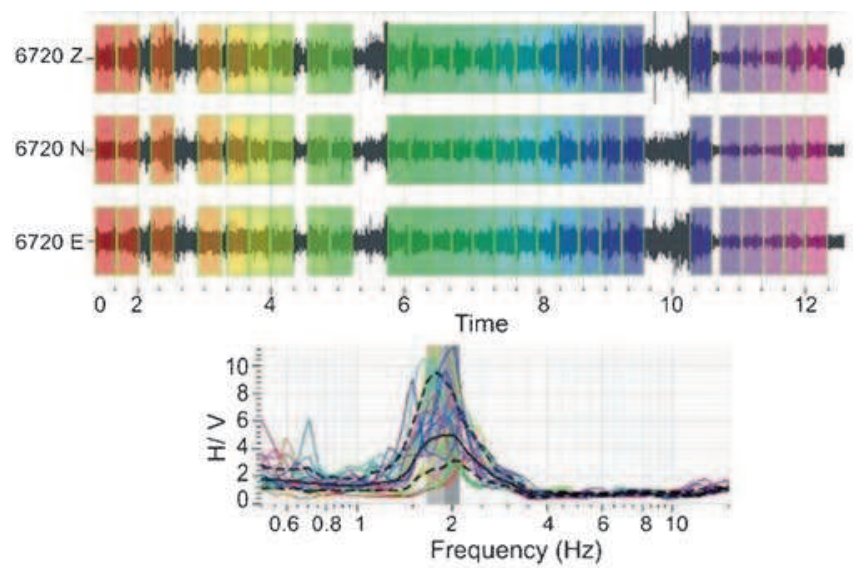

(a)
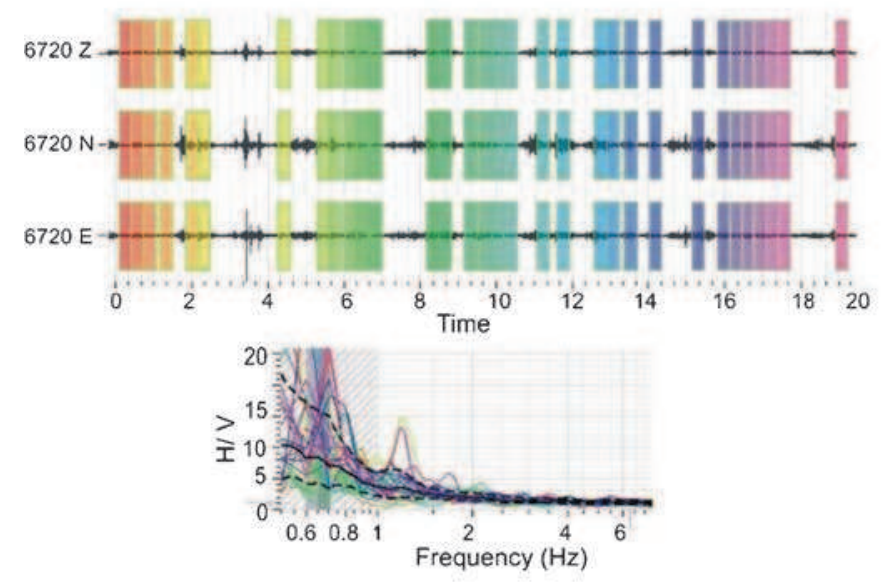

(c)
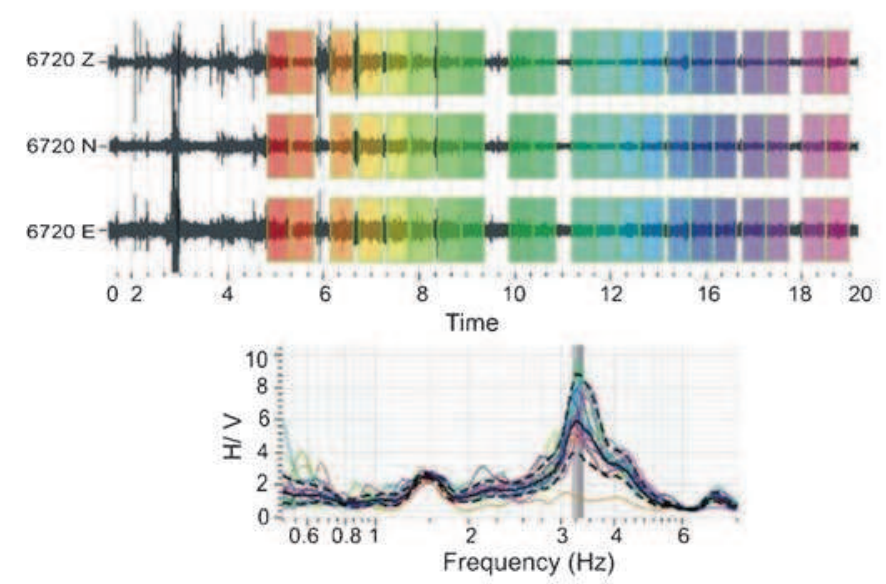

(e)
1998; Zaslavsky et al. 2000; Fah et al. 2001; Dikmen and Mirzaoğlu 2005; Asten 2006; BonnefoyClaudet et al. 2006; Hasancebi and Ulusay 2006; Eskişar et al. 2013; Asten et al. 2014; Akkaya 2015). According to these studies, the HVSR method can

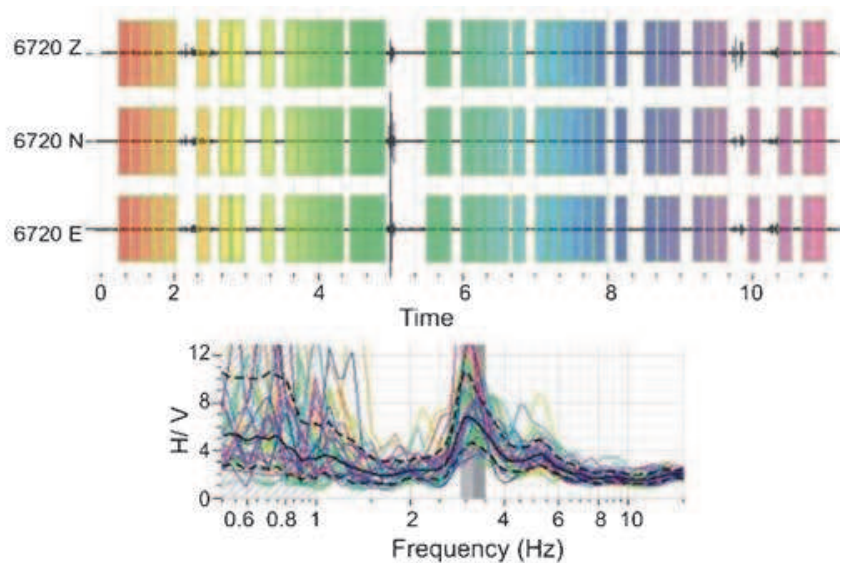

(b)
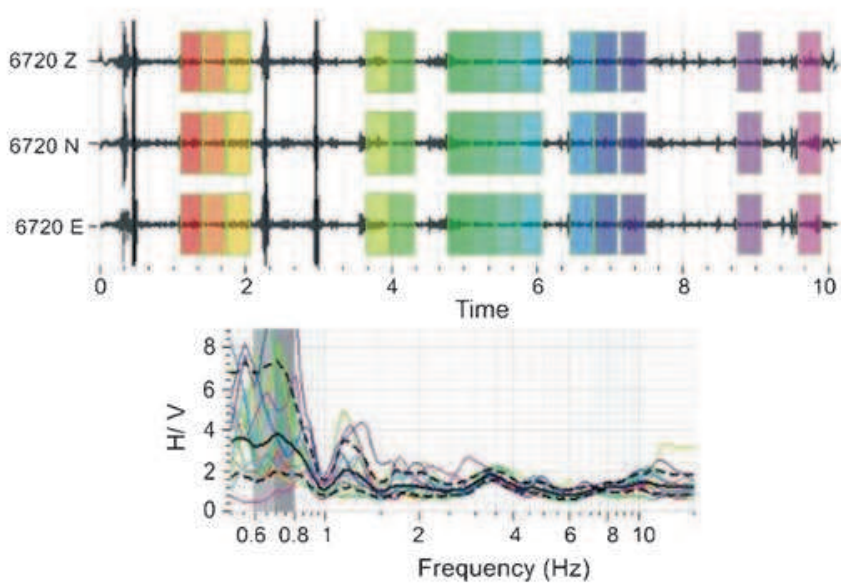

(d)
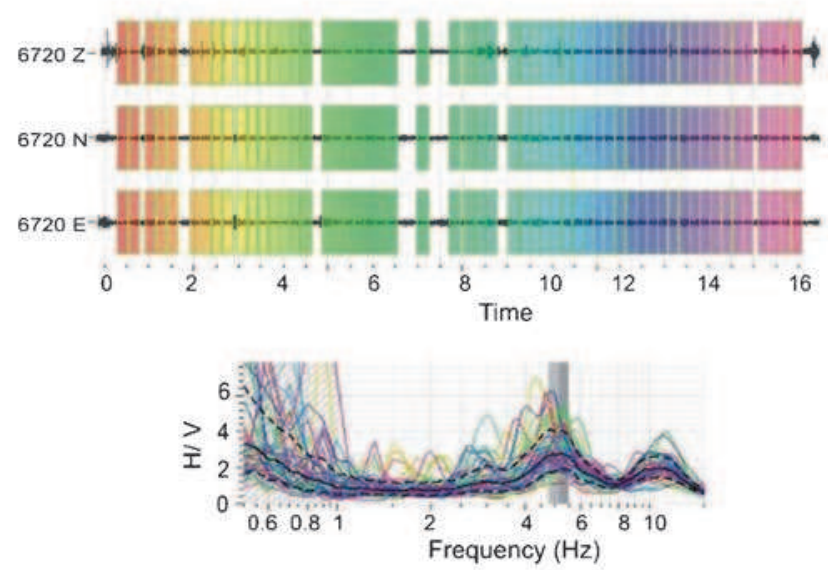

(f)

Figure 6. Interpretation of data obtained from the microtremor measurements in the study area; in the figure, there are two dotted lines above and below which is standard deviation for all values of the ratio of the resulting spectra. The line in the middle is the average value of the FFT analysis of the HVSR value, while the thin line is colourful curves HVSR of each window ((a)Bardakçı, (b) Göllü, (c) Dağönü, (d) Adıgüzel, (e) Timar (Gedikbulak), (f) Çolpan)). 
generally provide a very good estimation of the fundamental frequency (peak frequency or period of HVSR) of the sites in terms of their soil properties.

HVSR measurements were recorded using a CMG-6TD model seismograph equipped with three components, which was designed by Güralp Systems. At each station, the HVSR measurements were recorded for a duration of 10-30 min at 80 different locations in order to identify the soil conditions. Measurements were recorded in accordance with Nakamura (1989) HVSR method. Peak frequency and peak amplitude values of HVSR for the villages were determined by following the conventional data processing steps by the data obtained from HVSR measurements. These measurements were recorded under suitable environmental conditions, where there is no wind and rain by means of stable installation of seismometer on the ground and controlling the accuracy of the level. HVSR analysis in this study was performed following the rules outlined in (SESAME 2004). Measurements were recorded within a sampling interval of $100 \mathrm{~Hz}$ $(\mathrm{dt}=0.01 \mathrm{~s})$. Each window is base-line corrected for anomalous trends, tapered with Hanning window and a Butterworth band-pass filtered from $0.1 \mathrm{~Hz}$ low-cut to $10 \mathrm{~Hz}$ high-cut frequencies. The data obtained for each component, between 10 and $30 \mathrm{~s}$ in window length, is used to calculate HVSR values. The Fourier amplitude spectra of each selected window are computed and smoothened after merging two horizontal components by applying their geometric means (Site EffectS assessment using AMbient Excitation (SESAME) 2004). FFT (Fast Fourier Transform) was applied to each window using frequency-domain analysis. A horizontal-to-vertical spectral ratio was calculated for each range and spectral ratio. The standard deviation referring to the measurement point was also calculated using the average of calculated spectral values. The spectra, which was obtained using Parzen-window method, was computed using a cosine taper with $10 \%$ smoothing and KonnoOhmachi smoothing with a constant value of 40 (Konno and Ohmachi 1998). After smoothing the spectral ratio curves and processing the raw data as described above, the maximum HVSR peak
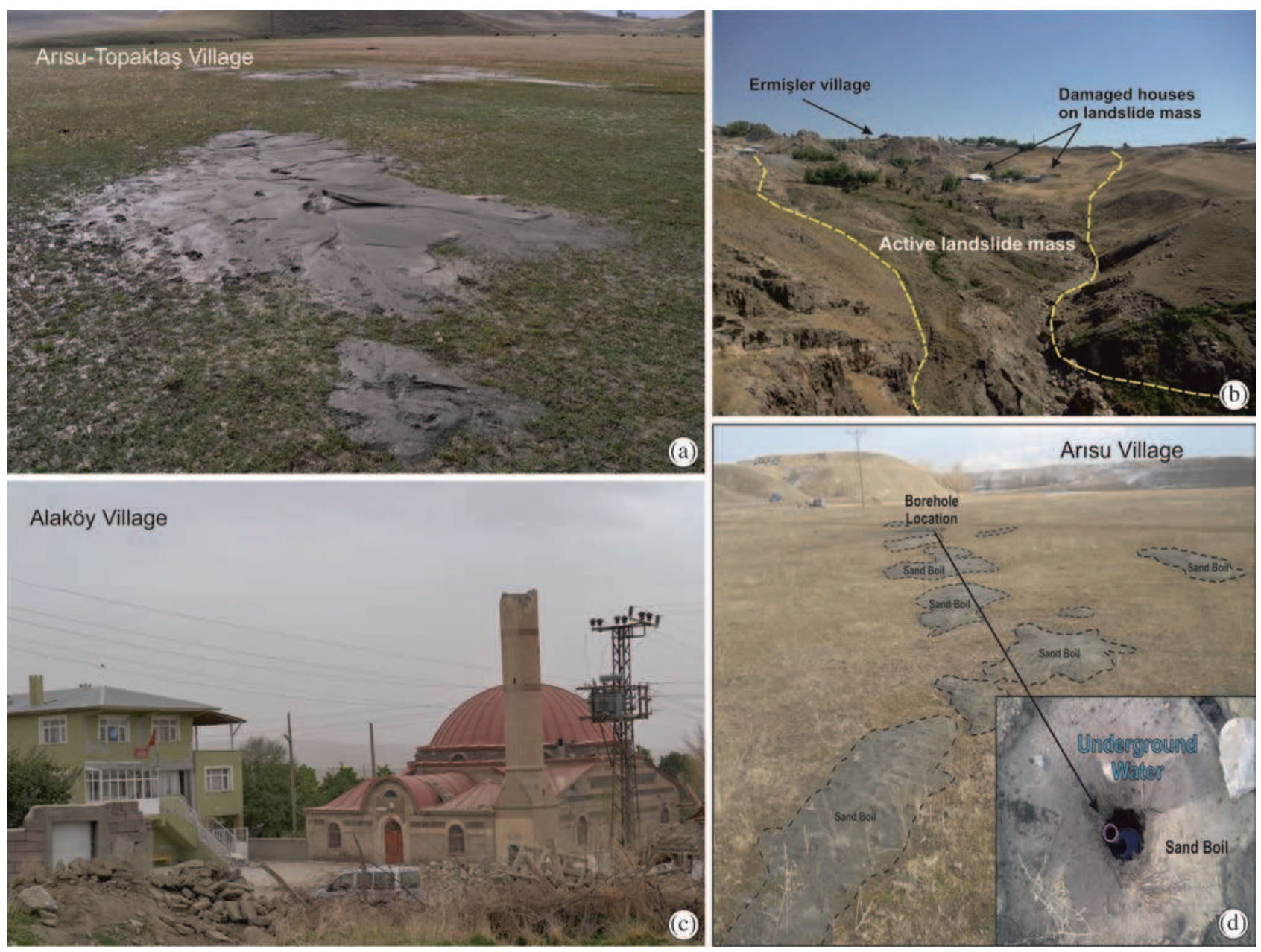

Figure 7. Earthquake-induced damages in the study area; (a) liquefaction, (b) landslide, (c) hillside effect, and (d) underground water effect. 
period values and HVSR peak amplitude values were obtained by using the Nakamura method (figure 5 , table 1 ). With the evaluation of the spectral curves obtained through the analysis, HVSR peak period and the corresponding increased rate in HVSR peak amplitude are determined (figure 6). The Geopsy software packages prepared by the SESAME were used in order to process the data obtained.

\section{Results}

HVSR method is applied to 80 microtremor measurements to provide information related to site response of the study area (figure 5). HVSR peak period values were found to be between 0.2 and $1.6 \mathrm{~s}$ and HVSR peak amplitude values were found between 4 and 10, respectively, in the villages that were severely damaged by the earthquake. HVSR peak period values of $0.1 \mathrm{~s}$ and HVSR peak amplitude values of 1.5-2 were obtained from the microtremor measurements, which were conducted in the villages that have minor damages caused by the earthquake (Çolpan, Çakırbey, Halkalı, Karaağaç, Sağlamtaş, Yayliyaka). This location over the rock area shows quite smaller peaks at lower periods.
The level of damage in the villages that are settled on lacustrine and stream sediments (Arısu, Mollakasım, Alaköy, Bardakçı, Topaktaş, Özkaynak, Gülsünler, Kasımoğlu, Satıbey, Koçköy, Yumrutepe, Atmaca, Göllü, Güveçli, Tabanlı, Dağönü, Şahgeldi, Yeşilsu, Ocaklı, Pirgarip, Hıdır and Aşağıgölalan) has verified that the damage correlates well with comparatively high HVSR peak period values and HVSR peak amplitude values that were in the range of $1.0-1.6 \mathrm{~s}$ and $6-9$, respectively. The probability of liquefaction (Akin et al. 2013) has increased in these villages (Arisu and Topaktas villages) due to the shallow groundwater level and the sandy soil layer.

Other severely damaged villages (Çitören, Arısu, Mollakasim, Alaköy, Yumrutepe, Atmaca, Göllü, Güveçli, Tabanl, Dağönü, Şahgeldi, Yeşilsu, Ocaklı, Pirgarip, Hıdır, Aşağıgölalan, Esenpınar, Sağlamtaş, Cakurbey) were located on the OligoceneMiocene aged deposits. The values of mid-range HVSR peak period, obtained in these villages, are compatible with geological characteristics of the region (0.4-0.8 s). High HVSR peak period and HVSR peak amplitude values were obtained, correlating with occurrence of liquefaction, in the villages of Bardakçı, Topaktaş, Özkaynak, Gülsünler, Kasımoğlu, Satıbey and Koçköy (figure 7a).

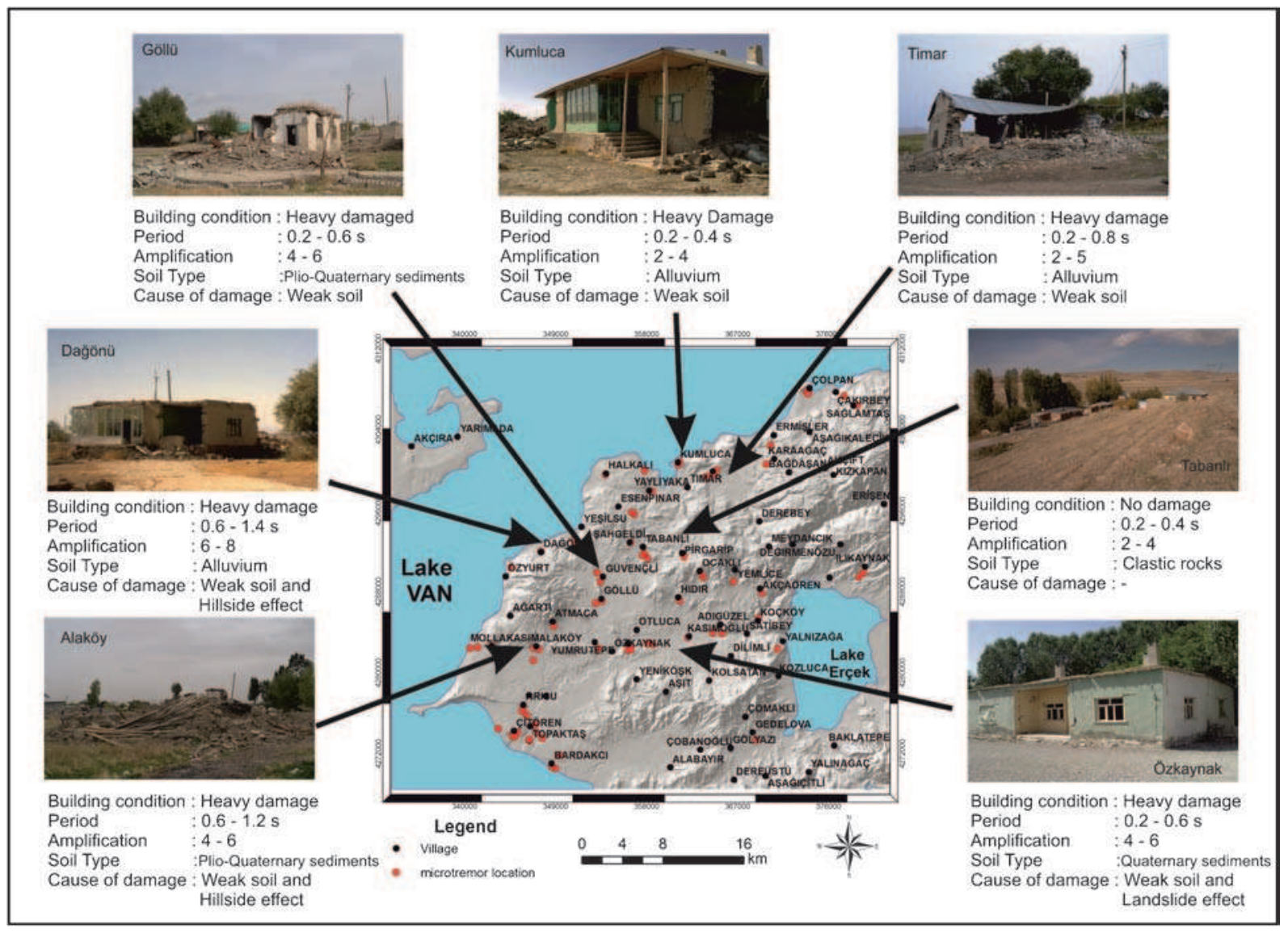

Figure 8. Different types of earthquake-induced structural damages in investigated villages. 
For Halkalı, Çolpan, Çakırbey, Sağlamtaş, Karaağaç, Kumluca and Yaylıyaka villages located on volcanic units and lacustrine deposits, the HVSR peak period levels are in the range of $0.1-0.2 \mathrm{~s}$ and HVSR peak amplitude values are in the range of 1.5-2. In general, the level of damage is minor; however, it increases in some parts of the villages, where the housing units are generally located on the locally found lacustrine sediments.

The results of this study are compared with the results of the final damage assessment report prepared by Governorship of Van and the relation between the damage levels to the buildings and the regional tectonics, local geological and geophysical conditions are given in table 1 . The results of this study are almost consistent with the results of the final damage assessment report prepared by Governorship of Van. However, it should be noted that the housing units severely damaged in villages located in volcanic areas, were constructed on locally found alluvial/lacustrine deposits (i.e., Halkalı, Yaylıyaka, Kumluca, Colpan and Esenpinar villages). The damages in Satıbey, Ermişler and Özkaynak villages are mainly because of the landslides (figure 7b).
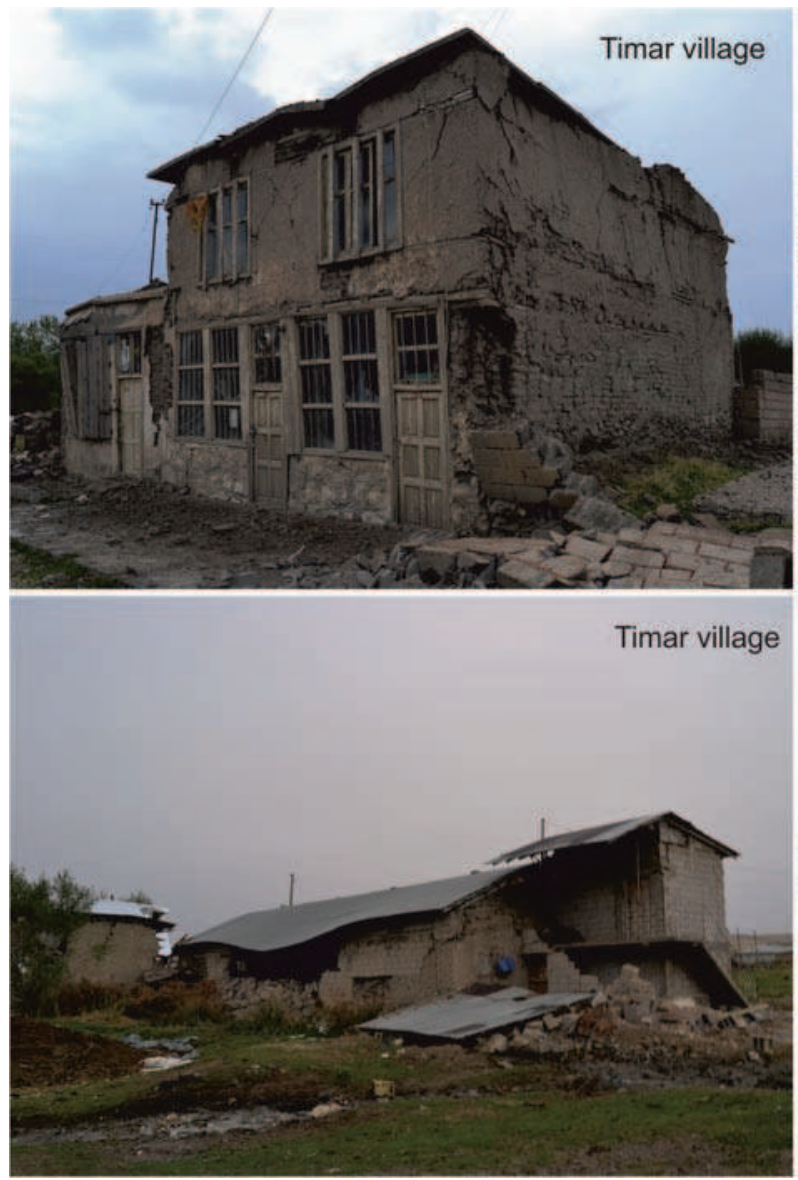

It was found that hillside effect, which is the translation of the body waves into surface waves in the edges of the basin, increased the amplitude value. The increase in the amplitude consequently resulted in higher levels of damages in housing units in Alaköy and Dağönü villages (figure 7c). Arısu and Güveçli villages are highly damaged due to underground water (figure $7 d$ ). Structural damages, which are related to the local soil conditions and the geological properties, are given in figure 8 .

\subsection{Structural damages of housing units}

The structural damages were severe and widespread in villages located on soft soils. A great majority of the existing housing units are unreinforced masonry buildings in these villages. The walls of relatively older housing units are mostly constructed with adobe blocks and mud mortar, whereas the newer units are constructed with light-weight concrete blocks and cement mortar (Tapan et al. 2013). There are also many housing units built with combination of these two different types of blocks, sometimes together with wooden structural materials (Tapan et al. 2013).
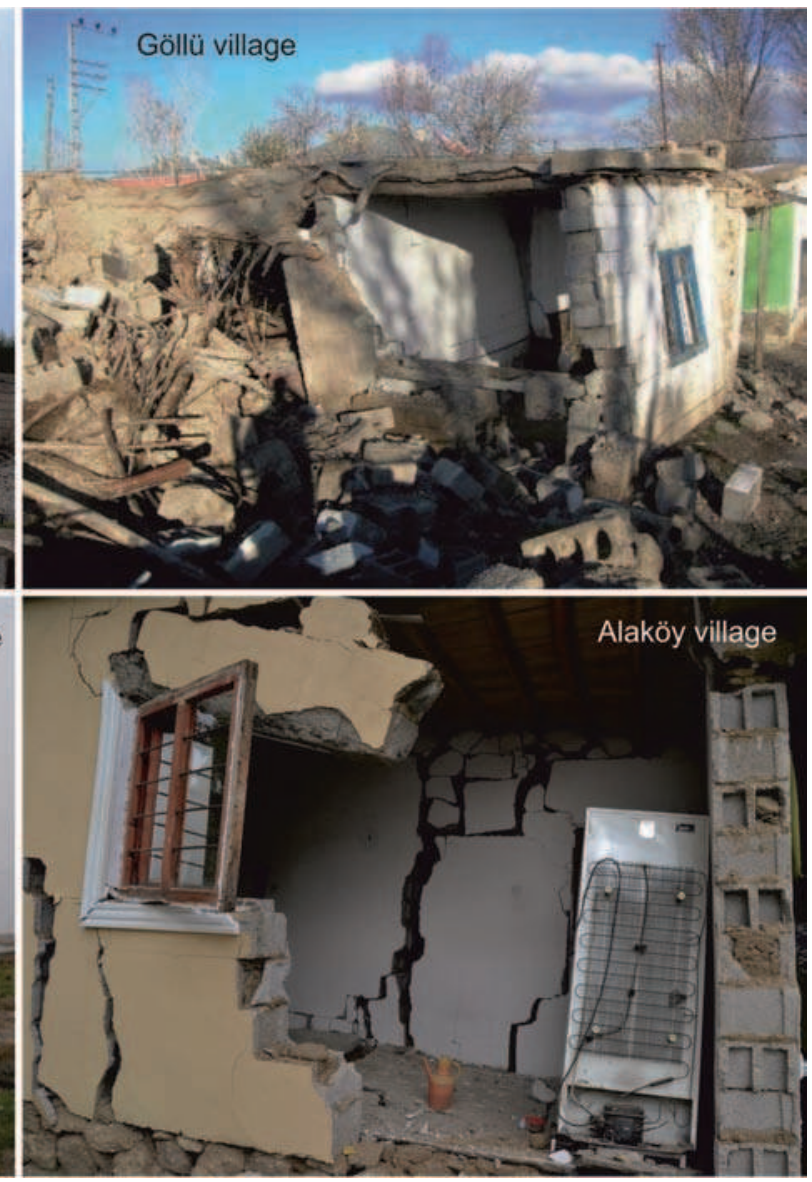

Figure 9. Damages to unreinforced masonry buildings on weak soils in the study area. 
The roofs of these housing units, particularly for relatively older ones, are built by woodwork and covered with a thick layer of clay for heat insulation. Although construction practice of all housing units are similar in the region, damages to the housing units located on strong soils such as rock units were relatively less than the damages of housing units located on weak soils (figure 9).

\section{Conclusion}

Reliable seismic hazard analyses require adequate consideration of local site effects. Experiences from the past earthquakes have revealed that soil conditions play an important role on seismic wave amplification phenomena and seen as one of the important parameters responsible for the level of damage. Good knowledge of local geotechnical features is required in order to consider local site effects (also known as the transfer function) in analyses. Therefore, determination of soil conditions constitutes a basic stage in earthquake engineering studies.

The structural damages caused by Van earthquake, have shown the importance of quality of construction as well as the seismic wave phases, earthquake mechanism, earthquake source properties, rupture direction, and local geotechnical conditions. Although, construction practices of all rural housing units are similar in the region, the earthquake caused massive damage to villages located on soft soils in northern region of the city.

The damage level of severely damaged villages that are settled on lacustrine and stream sediments was verified with comparatively higher HVSR peak period and peak amplitude values. It was also found that hillside effect, which is the translation of the body waves into surface waves in the edges of the basin, increased the amplitude values. The increase in the amplitude values consequently resulted in higher levels of damages in housing units.

HVSR peak period and peak amplitude values obtained in this study are almost consistent with the level of damage in housing units. However, this correlation seemed to be decreased in alluvial soils. Therefore, it is concluded that site characteristics (peak frequency of HVSR), wave amplification, and ground vulnerability are affected by sediment type, location, and thickness of sedimentary units.

Finally, this study shows that local soil conditions directly affect the level of damage in the structures after an earthquake. Therefore, it is important to consider dynamic properties of soil while designing the structures.

\section{Acknowledgements}

This study was financially supported by the Scientific Research Projects Office of Yüzüncü Yll University (YYU-BAP, Project No. 2012-HIZMiM002). The authors would like to thank Dr. Ünal Dikmen and Dr. Yavuz Özdemir for their support and guidance. They also thank Mesut BOR, for his help during the field studies. The manuscript proofreading was done by Blue Tower Educational Services. The authors are grateful to the reviewers for their valuable comments and suggestions.

\section{References}

Acarlar M, Bilgin E, Elibol E, Erkal T and Gedik İ 1991 Van Gölü Doğu ve Kuzeyinin Jeolojisi; MTA Jeoloji Etütler Dairesi, Derleme No: 1061, Ankara.

AFAD (Disaster and Emergency Management Directorate) 2011 About October 23, 2011 Van Earthquake report, http://www.afad.gov.tr, December 2011, 98p.

Akın M, Özvan A, Akın M and Topal T 2013 Evaluation of liquefaction in Karasu river flood plain after the October 23, 2011, Van (Turkey) earthquake; Nat. Hazards, doi: 10.1007/s11069-013-0763-2.

Akkaya İ 2015 The application of HVSR microtremor survey method in Yüksekova (Hakkari) region, eastern Turkey; J. African Earth Sci., doi: 10.1016/j.jafrearsci.2015.05. 018.

Akkaya İ and Köse O 2002 Van Gölü Havzası'nda Depremselliğin Periyodik Tekrarlanma Olasılı̆̆ı, 55. Türkiye Jeoloji Kurultayı, TMMOB Jeoloji Mühendisleri Odası, Bildiri Özleri Kitabı, 12, 2002, Ankara (in Turkish).

Aksoy E and Tatar Y 1990 Van İli doğu-kuzeydoğu yöresinin stratigrafisi ve tektoniği; TÜBITTAK Doğa Dergisi 14 628-644.

Ansal A 1999a Strong ground motions and site amplification; Theme lecture, In: 2nd Int. Conf. on Earthquake Geotechnical Engineering (ed.) Pinto P S, Balkema, Rotterdam 3 879-894.

Ansal A 1999b The cyclic behavior of soils and effects of geotechnical factors during 17 August 1999 Kocaeli earthquake; Earthquake Hazard and Risk in the Mediterranean Region, Nicosia 1 89-104.

Asten W M 2006 On bias and noise in passive seismic data from finite circular array data processed using SPAC methods; Geophysics 71(6) V153-V162.

Asten M W, Askan A, Ekincioğlu E E, Sisman N F and Ugurhan B 2014 Site characterization in northwestern Turkey based on SPAC and HVSR analysis of microtremor noise; Exploration Geophysics, doi: 10.1071/EG12026.

Bard P Y 1998 Microtremor measurements: A tool for site effect estimation; Proceedings of 2nd International Symposium on the Effect of Surface Geology on Seismic Motion, 1-3 December, Yokohama, Japan.

Bard P Y 2008 The H/V technique: Capabilities and limitations based on the results of the SESAME project; Foreword. Bull. Earthq. Eng. 6 1-2.

Bonnefoy-Claudet S, Cotton F and Bard P-Y 2006 The nature of noise wavefield and its applications for site effects studies: A literature review; Earth-Sci. Rev. 79 205-227. 
Çiftci Y, Selcuk L, Özvan A, Akkaya İ, Sengül M A and Aras B 2004 Seismic risk analysis for the settlements in the basin of Lake Van, Turkey; In: Proceedings of 5th International Symposium on Eastern Mediterranean Geology, Thessaloniki, Greece, 2 964-966.

Degens E T, Wong B K, Kutman F and Finckh P 1978 The Geology of Lake Van; MTA Publishing, No. 169, 147158.

Dikmen Ü and Mirzaoğlu M 2005 The seismic microzonation map of Yenisehir-Bursa, NW of Turkey by means of ambient noise measurements; Balkan Geophys. Soc. 8(2) 53-62.

Eskişar T, Özyalın Ş, Kuruoğlu M and Yılmaz H R 2013 Microtremor measurements in the northern coast of Izmir Bay, Turkey to evaluate site-specific characteristics and fundamental periods by $\mathrm{H} / \mathrm{V}$ spectral ratio method; $J$. Earth Syst. Sci. 122(1) 123-136.

Fah D, Kind F and Giardini D 2001 A theoretical investigation of average $\mathrm{H} / \mathrm{V}$ ratios; Geophys. J. Int. 145 535549.

Field E H and Jacob K H 1995 A comparison and test of various site-response estimation techniques, including three that are not reference-site dependent; Bull. Seismol. Soc. Am. 85(4) 1127-1143.

Gitterman Y, Zaslavsky Y, Shapira A and Shtivelman V 1996 Empirical site response evaluations: Case studies in Israel; Soil Dyn. Earthq. Engg. 15 447-463.

Göncüoğlu M C and Turhan N 1984 Geology of the Bitlis metamorphic belt; In: Geology of the Taurus Belt (eds) Tekeli $\mathrm{O}$ and Göncüoğlu M C, Proceedings of the International Symposium on the Geology of the Taurus Belt, 26-29.9.1983, Ankara, pp. 237-244.

Güner Y 1984 Nemrut yanardağının jeolojisi, jeomorfolojisi ve volkanizmasının evrimi; Jeomorfoloji Dergisi 12 23-65 (in Turkish).

Hasancebi N and Ulusay R 2006 Evaluation of site amplification and site period using different methods for an earthquake-prone settlement in western Turkey; Eng. Geol. 87 85-104.

Kanai K and Tanaka T 1954 On microtremors I; Bull. Earthq. Res. Inst. 32 199-209.

Kanai K and Tanaka T 1961 On microtremors VIII; Bull. Earthq. Res. Inst., University of Tokyo 39 97114 .

Ketin I 1977 A short explanation about the results of observations made in the region between Lake Van and Iranian border; Bull. Geol. Soc. Turk. 20 79-85 (in Turkish).

Konno K and Ohmachi T 1998 Ground-motion characteristics estimated from spectral ratio between horizontal and vertical components of microtremor; Bull. Seismol. Soc. Am. 88 228-241.

Koçyiğit A, Yilmaz A, Adamia S and Kulashvili S 2001 Neotectonics of East Anatolian Plateau (Turkey) and Lesser Caucasus: Implication for transition from thrusting to strike-slip faulting; Geodinamica Acta 14 177195.

Koçyiğit A, Deveci Ş and Kaplan M 2011 Van Depremleri Raporu, 23 Ekim-30 Kasım 2011; Ortadoğu Teknik Ünivesitesi, Aktif Tektonik ve Deprem Araştırma Lab. Yayını, Ankara, Türkiye, 22p.

KOERI 2011 Probabilistic assessment of the seismic hazard for the Lake Van basin, October, 23 2011; www.koeri. boun.edu.tr.

Lachet C and Bard P Y 1994 Numerical and theoretical investigations on the possibilities and limitations of Nakamura's technique; J. Phys. Earth 42 377-397.
Lachet C, Hatzfeld D, Bard P Y, Theodulidis N, Papaioannou C and Savvaidis A 1996 Site effects and microzonation in the city of Thessaloniki (Greece); Bull. Seismol. Soc. Am. 86 1692-1703.

Lermo J and Chavez-Garcia F J 1993 Site effect evaluation using spectral ratios with only one station; Bull. Seismol. Soc. Am. 83 1574-1594.

Lermo J and Chavez-Garcia F J 1994 Are microtremors useful in site response evaluation? Bull. Seismol. Soc. Am. 84 1350-1364.

Lunedei E and Albarello D 2010 Theoretical HVSR curves from full wavefield modelling of ambient vibrations in a weakly dissipative layered earth; Geophys. J. Int. 181 1093-1108, doi: 10.1111/j.1365-246X.2010.04560.x.

Mucciarelli M 1998 Reliability and applicability of Nakamura's technique using microtremors: An experimental approach; J. Earthq. Engg. 4 625-638.

MTA 2007 Van İlinin Yer Bilim Verileri, Ankara.

MTA 2008 Van K50 Paftası Jeoloji Haritası, Ankara.

Nakamura Y 1989 A method for dynamic characteristics estimation of subsurface using microtremor on the ground surface; Quarterly Report of Railway Technical Research Institute (RTRI) 30 25-33.

Nakamura Y 2008 On the H/V Spectrum; The 14th World Conference on Earthquake Engineering, October 12-17, 2008, Beijing, China.

Ozel O, Sasatani T, Kudo K, Okada H, Kano T, Tsuno S, Yoshikawa M, Noguchi S, Miyahara M and Goto H 2004 Estimation of S-wave velocity structures in Avcilar Istanbul from array microtremor measurements; J. Fac. Sci. Hokkaido Uni. Series VII (Geophysics) 12(2) 115-129.

Özvan A, Akkaya İ, Tapan M and Şengül M A 2005 Van yerleşkesinin deprem tehlikesi ve olasıbir depremin sonuçları, Deprem Sempozyumu Kocaeli 2005, 23-25 Mart 2005, Kocaeli.

Pilz M, Parolai S, Leyton F, Campos J and Zschau J 2009 A comparison of site response techniques using earthquake data and ambient seismic noise analysis in the large urban areas of Santiago de Chile; Geophys. J. Int. 178(2) 713-728.

Poyraz S A, Şengül M A and Pınar A 201123 Ekim 2011 Van-Tabanlı Depremi Kaynak Mekanizmasıve Sismotektonik Yorumu; Istanbul Yerbilimleri Dergisi 24(2) 129-139.

SESAME 2004 Site effects assessment using ambient excitations: Final Report, European Commission Research General Directorate, Project EVG1-CT-2000-00026 SESAME.

Şaroğlu F and Güner Y 1981 Doğu Anadolu'nun jeomorfolojik gelişimine etki eden ögeler: Jeomorfoloji, tektonik, volkanizma ilişkileri; Türkiye Jeol. Kur. Bült. 24 39-50.

Şengör A M C and Kidd W S F 1979 Post-collisional tectonics of the Turkish-Iranian plateau and a comparison with Tibet; Tectonophys. 55 361-376.

Suzuki T, Adachi Y and Tanaka M 1995 Application of microtremor measurements to the estimation of earthquake ground motions in Kushiro city during the KushiroOki earthquake of 15 January 1993; Earthq. Eng. Struct. Dyn. 24 595-613.

Tapan M, Cömert M, Demir C, Sayan Y, Orakcal K and Ilki A 2013 Failures of structures during the October 23, 2011 Tabanlı (Van) and November 9, 2011 Edremit (Van) earthquakes in Turkey; Engineering Failure Analysis, doi: 10.1016/j.engfailanal.2013.02.013.

Ternek Z 1953 Geological study of southeastern region of Lake Van; Geol. Soc. Turkey Bull. 4(2) 1-32. 
Theodulidis N, Bard P Y, Archuleta R and Bouchon M 1996 Horizontal-to-vertical spectral ratio and geological conditions: The case of Garner valley downhole in southern California; Bull. Seismol. Soc. Am. 68 767-779.

Yılmaz Y, Dilek Y and Işık H 1981 Gevaş (Van) ofiyolitinin jeolojisi ve sinkinematik bir makaslama zonu; Türkiye Jeoloji Kurumu Bülteni 24 37-44.
Yılmaz Y, Şaroğlu F and Güner Y 1987 Initiation of the Neomagmatism in East Anatolia; Tectonophys. 134 177199.

Zaslavsky Y, Sapira A and Arzi A 2000 Amplification effects from earthquakes and ambient noise in the Dead Sea rift (Israel); Soil Dyn. Earthq. Engg. 20 187207. 